Сергій Горбачевський, кандидат технічних наук, старший науковий співробітник Національний університет оборони України імені Івана Черняховського, м. Київ

ORCID ID 0000-0002-4946-1604

DOI: $10.33099 / 2617-1775 / 2020-02 / 120-128$

\title{
ІНФОРМАЦІЙНА СИСТЕМА ОЦІНКИ ПРОФЕСІЙНИХ КОМПЕТЕНТНОСТЕЙ ОФІЦЕРІВ - ВИПУСКНИКІВ ВИЩИХ ВІЙСЬКОВИХ НАВЧАЛЬНИХ ЗАКЛАДІВ ТАКТИЧНОГО РІВНЯ
}

Запропоновано структуру інформаційної системи оцінки професійних компетентностей офічерів - випускників вищих військових навчальних закладів тактичного рівня та описано макет системи на базі системи дистанційного навчання.

Ключові слова: інформаційна система; професійні компетенції офіщуерів; вищзі військові навчальні заклад; військова освіта; дистанційне навчання.

Постановка проблеми. Цифрові технології швидко змінюють сучасність, особливо, систему освіти. При цьому цифровізація освіти змінює і підходи до оцінки якості освіти. На етапі навчання курсантів (слухачів) ступінь цифровізації освітнього процесу та процесу оцінювання якості освіти вже $\epsilon$ високою, в першу чергу, завдяки системі дистанційного навчання. А ось збір відгуків про випускників вищих військових навчальних закладів (ВВН3) i їх обробка досі переважно ручна, хоча $є$ всі передумови і можливості щодо іiі автоматизації.

Відгуки на випускників ВВНЗ є головною формою зворотного зв'язку про якість підготовки випускників. Загалом система підготовки відгуків на випускників, їх збору та аналізу має бути елементом загальної системи управління якістю освіти та одною 3 підсистем підтримки прийняття рішень керівника військової освіти.

Аналіз публікацій. Питання ролі відгука на випускника ВВНЗ у системі управління якістю підготовки військових фахівців досить детально розглянуті у роботах Зельницького А.М. [1-2] та монографії [3], але ці роботи не враховують сучасні можливості інформаційних систем.

Метою статті $\epsilon$ розробка вимог до інформаційної системи оцінки професійних компетентностей офіцерів шляхом збору та обробки відгуків на випускників ВВНЗ та ВНП ЗВО.

Виклад основного матеріалу. Відгук на випускника $\epsilon$ його першою атестаційною процедурою у військах (силах), що дозволяє аналізувати рівень військово-професійного зростання військового фахівця при його атестуванні. Аналіз досвіду використання існуючої паперової системи відгуків на випускників ВВНЗ та ВНП ЗВО показує, що вона має певні недоліки, а саме:

- відсутність гнучкості, тому що форма відгуку єдина для всіх видів до родів військ та рівнів освіти; 
- низькій відсоток збору відгуків, тому що складається у паперовому вигляді та складної процедури затвердження відгуку командуванням частини;

- високі працевтрати на збір та обробку відгуків;

- низьку достовірність результатів відгуків.

Сучасні інформаційні технології можуть спростити технологію відгуку, зменшити витрати на систему та розширити можливості системи за рахунок спеціалізованих питань у відгуку, а також залучення до самооцінки самих випускників.

Кожна компетентність стандарту вищої освіти за спеціальністю та професійного стандарту офіцера тактичного рівня містить професійно важливі якості, прояв яких визначається сформованістю відповідних знань, умінь та навичок, які необхідні для виконання випускниками в майбутньому службових (бойових) функцій у військах (силах) на відповідній посаді за призначенням.

Вивчення професійної (службової) діяльності офіцера-випускника (виконання ним службових (бойових) функцій) на протязі першого року служби у військах (силах) та їі оцінювання здійснюється командирами (начальниками) всіх рівнів у процесі повсякденної служби, за результатами яких складається відгук, який направляється до ВВНЗ та ВНП ЗВО, який він закінчив.

Оцінювання професійної (службової) діяльності має важливе значення в забезпеченні успішної адаптації молодих офіцерів. Цей процес постійного спостереження, вивчення і оцінювання професійної (службової) діяльності за визначеними критеріями результатів його діяльності та прояви якостей являє собою дієвий інструмент виважених кадрових рішень в процесі якісного управління кар' єрою офіцерів. Командири (начальники) впродовж подальшого професійного становлення молодих офіцерів уважно відслідковують їх успіхи та помилки, що використовується у ході усунення недоліків у освітньому процесі.

Збір і аналіз відгуків, узагальнення результатів професійної (службової) діяльності випускників у військах та розробка рекомендацій щодо удосконалення навчальних планів, програм навчальних дисциплін, які забезпечують формування необхідних компетентностей, методів та методик 3 підготовки військових фахівців у ВВНЗ та ВНП $3 \mathrm{BO} \epsilon$ важливою складовою освітнього процесу.

До показників якості, з яких складається відгук, висуваються пєвні вимоги. Вони повинні бути

- суттєвими;

- вимірювальними;

— репрезентативними та не повторювати інші;

- достовірними.

Тобто від якості складання форми відгуку залежить якість одержуваної для аналізу інформації. Для розробки змісту відгуку (Табл. 1) було проаналізовано перелік компетентностей, які мають бути сформовані за освітньою програмою зі спеціальності № 253 «Військове управління (за видами Збройних Сил)» за спеціалізацією «Управління діями підрозділів механізованих 
військ», кваліфікація: бакалавр військового управління підрозділами механізованих військ, офіцер тактичного рівня. Це найбільш поширена спеціалізація серед випускників ВВНЗ.

Таблиця 1

\begin{tabular}{|c|c|c|c|c|c|c|}
\hline \multirow{2}{*}{$\begin{array}{l}\text { № } \\
\text { 3/II }\end{array}$} & \multirow[b]{2}{*}{ Професійні важливі якості офіцера } & \multicolumn{5}{|c|}{ Оцінка в балах } \\
\hline & & 2 & 3 & 4 & 5 & $\begin{array}{l}\text { "ө" } \\
\text { не можу } \\
\text { оцінити }\end{array}$ \\
\hline & \multicolumn{6}{|c|}{ Правові (знання та виконання) } \\
\hline & $\begin{array}{l}\text { а) основ кримінального кодексу щодо військових } \\
\text { злочинів та відповідальності за них }\end{array}$ & & & & & \\
\hline & б) основ міжнародного гуманітарного права & & & & & \\
\hline & в) Статутів Збройних Сил України & & & & & \\
\hline & $\begin{array}{l}\text { a) основ кримінального кодексу щодо військових } \\
\text { злочинів та відповідальності за них }\end{array}$ & & & & & \\
\hline & б) основ міжнародного гуманітарного права & & & & & \\
\hline & \multicolumn{6}{|c|}{ Організаційно-управлінські (здатність і готовність) } \\
\hline & $\begin{array}{l}\text { a) підтримувати підрозділ у стані постійної бойової } \\
\text { готовності }\end{array}$ & & & & & \\
\hline & $\begin{array}{l}\text { б) планувати, організовувати та } \\
\text { повсякденну діяльність підрозділу }\end{array}$ & & & & & \\
\hline & $\begin{array}{l}\text { в) управляти повсякденною діяльністю підрозділу } \\
\text { через підпорядкований сержантський склад }\end{array}$ & & & & & \\
\hline & \multicolumn{6}{|c|}{ Загальновійськові, тактичні (здатність) } \\
\hline & $\begin{array}{l}\text { a) здійснювати підготовку та управляти підрозділом } \\
\text { під час виконання бойових (спеціальних) завдань, } \\
\text { проведення навчань, занять }\end{array}$ & & & & & \\
\hline & $\begin{array}{l}\text { б) приймати обгрунтовані рішення в складній } \\
\text { обстановці під час виконання бойових (спеціальних) } \\
\text { завдань, проведення навчань, занять }\end{array}$ & & & & & \\
\hline & в) вести (відпрацьовувати) бойові (звітні) документи & & & & & \\
\hline & \multicolumn{6}{|c|}{ Тактико-спеціальні (здатність) } \\
\hline & $\begin{array}{l}\text { a) організовувати і вести розвідку під час виконання } \\
\text { бойових (спеціальних) завдань, проведення навчань, } \\
\text { занять }\end{array}$ & & & & & \\
\hline & $\begin{array}{l}\text { б) організовувати і підтримувати стійкий зв'язок під } \\
\text { час під час виконання бойових (спеціальних) завдань, } \\
\text { проведення навчань, занять }\end{array}$ & & & & & \\
\hline
\end{tabular}


Закінчення таблиці 1

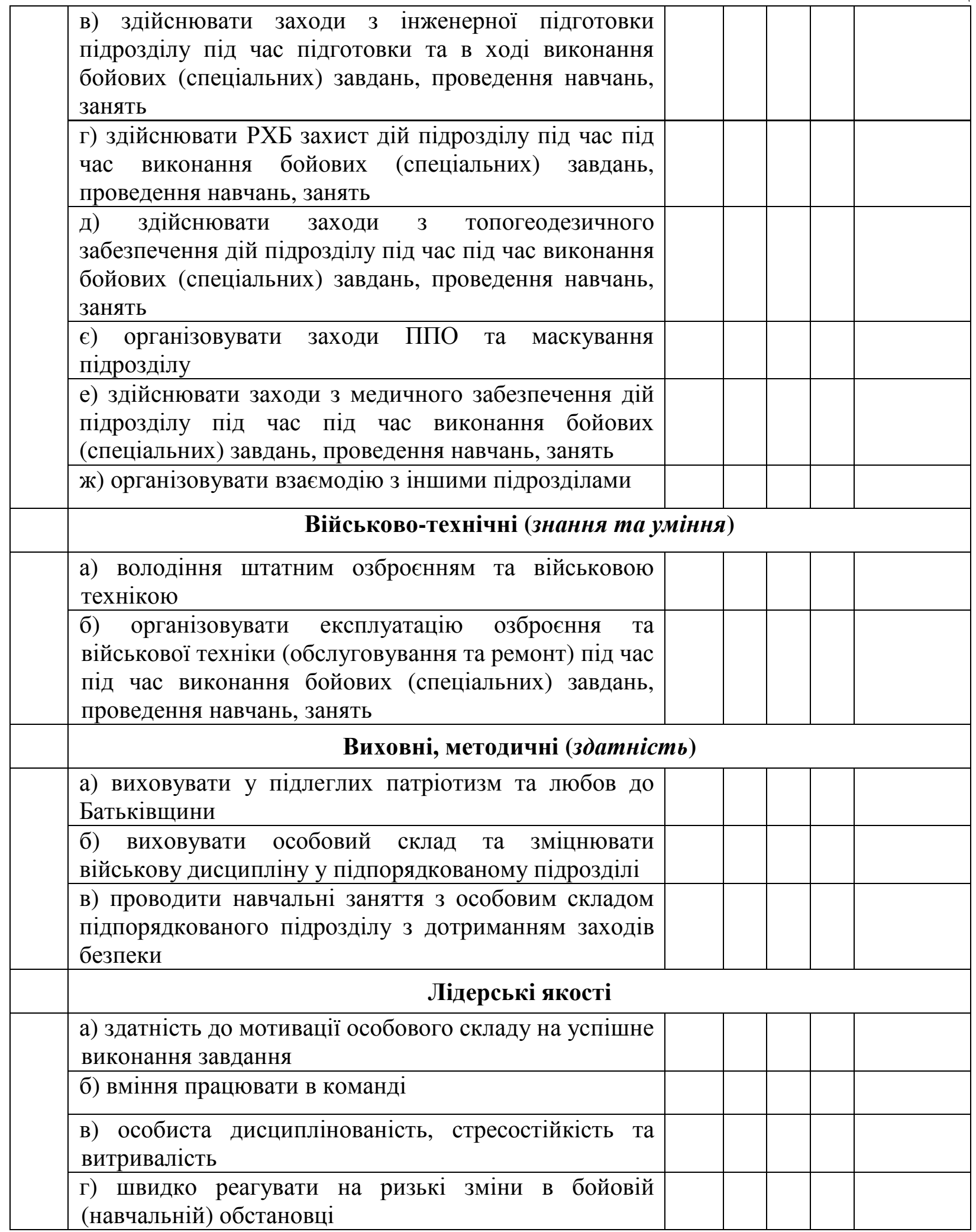

Крім відгуку командира пропонується до зворотного зв'язку додати:

- самооцінювання випускником ВВНЗ та ВНП ЗВО рівня власної готовності до виконання службових обов'язків на посаді призначення за період проходження офіцерської служби у військах (силах) протягом 1-го року (Табл. 1); 
- оцінювання викладання навчальних дисциплін, які формують військово-професійні та військово-спеціальні компетентності (Табл. 2);

Оцінювання викладання навчальних дисциплін, запропоновано визначати за двома групами показників - корисністю дисциплін (А) та можливими недоліками їх викладання (Б).

А1 - навчальна дисципліна максимально корисна;

А2 - навчальна дисципліна достатньо корисна;

А3 - навчальна дисципліна не чинить ж⿻оного впливу на формуванню відповідних компетентностей та професійно важливих якостей

Можливі недоліки позначаються шляхом вписування позначки “V" відповідний рядок одного із стовпчиків Б) таблиці 2, де:

Б1 - недостатньо часу на формування компетентності в межах відповідної навчальної дисципліни;

Б2 - недостатньо часу на теоретичні заняття 3 цієї навчальної дисципліни;

Б3. - недостатньо часу на практичні заняття з цієї навчальної дисципліни;

Б4 - недосконала (або відсутня) відповідна навчально-тренувальна база;

Б5 - низький рівень викладання цієї навчальної дисципліни;

Б6 - навчальна дисципліна, викладання якої мало би сприяти формуванню зазначеної компетентності, взагалі не включена в освітню програму.

Таблиця 2

\begin{tabular}{|c|c|c|c|c|c|c|c|c|c|c|c|}
\hline \multirow{2}{*}{$\begin{array}{c}\text { № } \\
3 / \Pi \\
1 \\
\end{array}$} & \multirow{2}{*}{$\begin{array}{c}\text { Перелік навчальних дисциплін } \\
2 \\
\end{array}$} & \multirow{2}{*}{\begin{tabular}{|c|} 
Кількість \\
кредитів
\end{tabular}} & \multicolumn{3}{|c|}{ Корисності } & \multicolumn{6}{|c|}{ Можливі недоліки } \\
\hline & & & A1 & $\mathrm{A} 2$ & A3 1 & Б1 & & Б3 & Б4 & Б5 & Б6 \\
\hline \multicolumn{12}{|c|}{$\begin{array}{l}\text { Перелік навчальних дисциплін військово-професійного спрямування програми } \\
\text { базової підготовки }\end{array}$} \\
\hline 1. & $\begin{array}{l}\text { Морально-психологічне забезпечення } \\
\text { підготовки та застосування Збройних } \\
\text { Сил України }\end{array}$ & 2 & & & & & & & & & \\
\hline 2. & Загальна тактика & 5 & & & & & & & & & \\
\hline 3. & $\begin{array}{l}\text { Основи військового управління (у } \\
\text { тому числі штабні процедури НАТО) }\end{array}$ & 4 & & & & & & & & & \\
\hline 4. & $\begin{array}{l}\text { Управління повсякденною діяльністю } \\
\text { підрозділів (у тому числі охорона } \\
\text { державної таємниці, безпека } \\
\text { життєдіяльності, основи охорони } \\
\text { праці, безпека військової діяльності) }\end{array}$ & 4 & & & & & & & & & \\
\hline 5. & $\begin{array}{l}\text { Радіаційний, хімічний, біологічний } \\
\text { захист підрозділів (у тому числі } \\
\text { екологія) }\end{array}$ & 3 & & & & & & & & & \\
\hline 6. & Військова топографія & 3 & & & & & & & & & \\
\hline 7. & Інженерна підготовка & 3 & & & & & & & & & \\
\hline 8. & Організація військового зв’язку, & 2 & & & & & & & & & \\
\hline 9. & $\begin{array}{l}\text { Бойова система виживання воїнів (у } \\
\text { тому числі тактична медицина) }\end{array}$ & 2 & & & & & & & & & \\
\hline
\end{tabular}


Закінчення таблиці 2

\begin{tabular}{|c|c|c|c|c|c|c|c|c|c|c|c|}
\hline 1 & 2 & 3 & $\mathrm{~A} 1$ & A2 & A3 & Б1 & Б2 & 53 & Б4 & 55 & 56 \\
\hline 10. & $\begin{array}{l}\text { Статути Збройних Сил України та їх } \\
\text { практичне застосування (у тому числі } \\
\text { стройова підготовка) }\end{array}$ & 3 & & & & & & & & & \\
\hline 11. & $\begin{array}{l}\text { Стрілецька зброя та вогнева } \\
\text { підготовка }\end{array}$ & 3 & & & & & & & & & \\
\hline 12. & $\begin{array}{l}\text { Фізичне виховання та спеціальна } \\
\text { фізична підготовка }\end{array}$ & 9 & & & & & & & & & \\
\hline 13. & $\begin{array}{l}\text { Іноземна мова (загальний, } \\
\text { загальновійськовий та спеціальний } \\
\text { курс) }\end{array}$ & 20 & & & & & & & & & \\
\hline 14. & $\begin{array}{l}\text { Правознавство (у тому числі основи } \\
\text { військового законодавства та } \\
\text { міжнародне гуманітарне право, } \\
\text { морське право для спеціальностей } \\
\text { підготовки військових фахівців } \\
\text { морського профілю) } \\
\end{array}$ & 2,5 & & & & & & & & & \\
\hline 15. & $\begin{array}{l}\text { Військова педагогіка та психологія (у } \\
\text { тому числі лідерство) }\end{array}$ & 2 & & & & & & & & & \\
\hline
\end{tabular}

Наразі у системі військової освіти $є$ як централізовані інформаційні системи на кшталт системи дистанційного навчання (СДН) на базі відповідного центру, так інформаційні освітні системи окремих ВВНЗ. Тому є різні шляхи побудови інформаційної платформи для роботи 3 відгуками. Зі своїми від'ємностями.

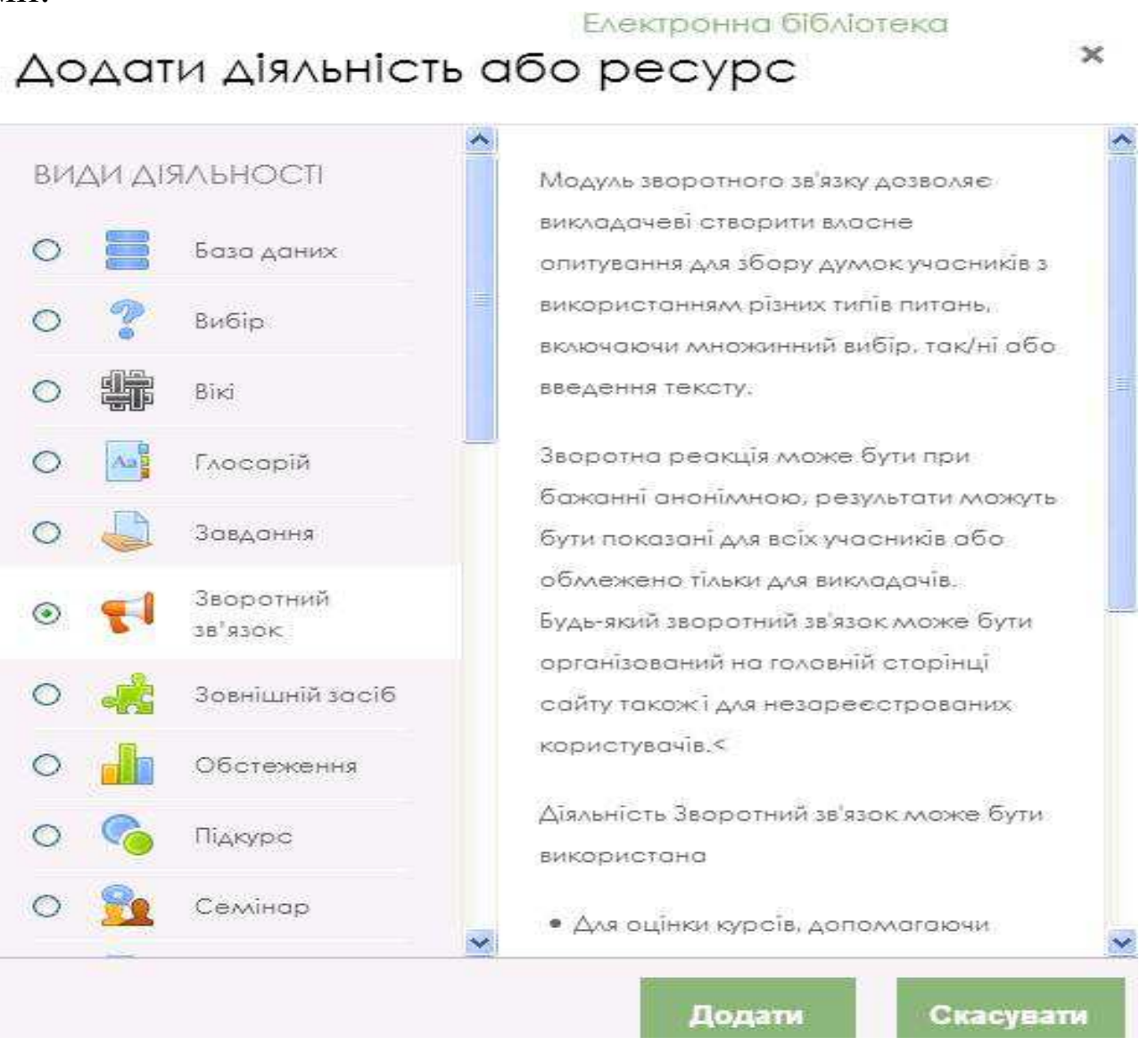

Рис. 1. Модуль зворотного зв'язку системи Moodle 
Найменш затратним $є$ шлях використання СДН на базі ПЗ Moodle [4]. В ньому є спеціальний компонент зворотного зв'язку (Рис. 1), в якому можна автоматизувати форму відгуку будь якої складності за досить короткий час без залучення фахівців з програмування.

Там є вбудована аналітика. I ця система використовує адаптивний дизайн, що дозволяє заповнювати форми в тому числі і на мобільних пристроях (смартфон, планшет тощо).

Вбудована аналітична форма дозволяє розрахувати середні показники оцінки за кожною компетентністю для кожної спеціалізації випускника ВВНЗ. Якщо середня оцінка нижче, ніж задовільна, то потребує аналізу матриця відповідності програмних компетентностей компонентів освітньо-професійної програми для внесення змін у освітній процес.

За допомогою цього компоненту біло розроблено макет автоматизованої системи збору та обробки відгуків на випускників, а також анкет самооцінювання шляхом додавання питань (Рис. 2) з таблиць 1 та 2.

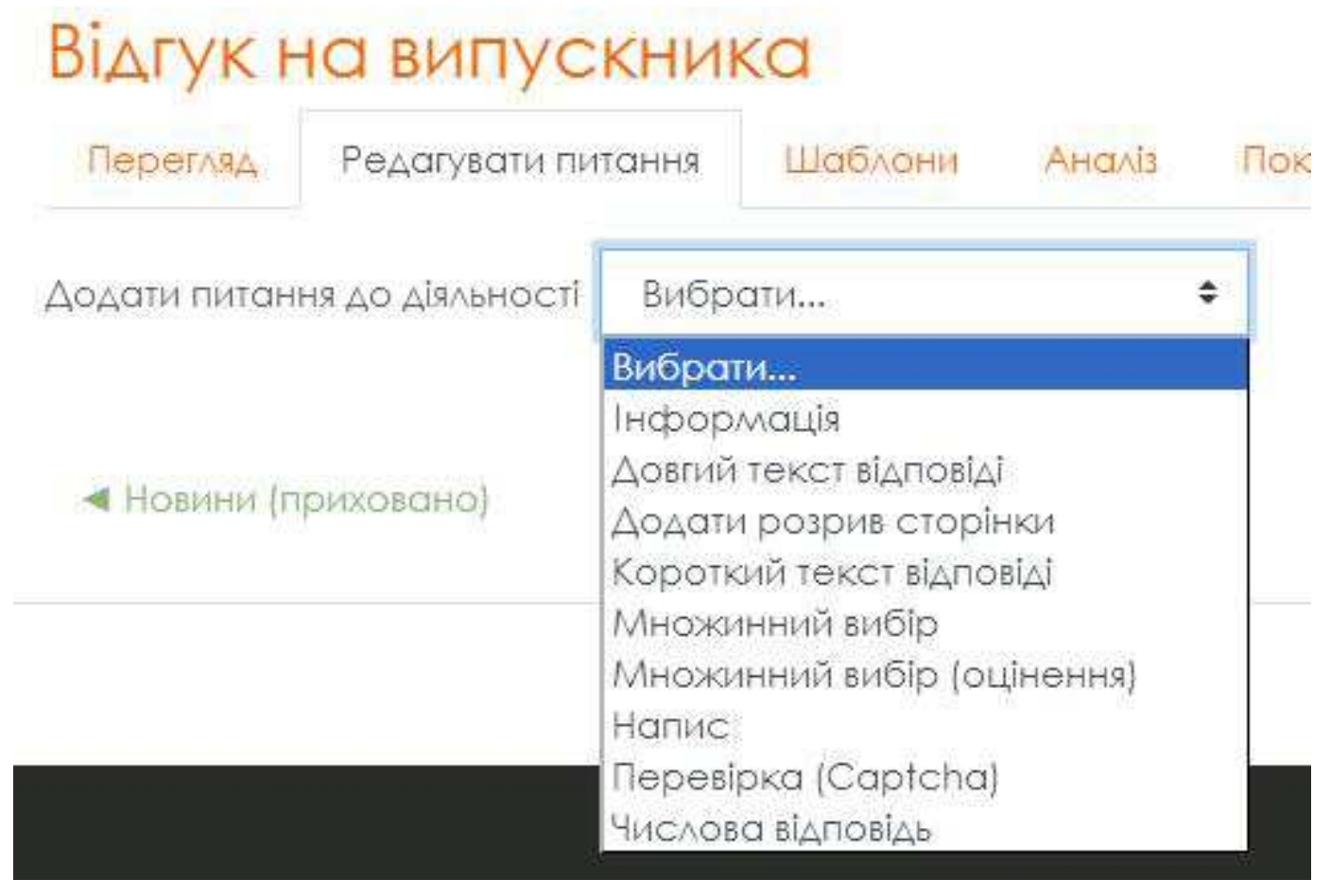

Рис. 2. Додавання до відгуку (анкети) різних типів питань

У такого підходу існують недоліки, а саме система обмежена набором стандартних функцій, все не стандартне треба дописувати на мові програмування php. В системі також немає шифрування, а тому досить слабкий захист персональних даних. Крім того, за логінами та паролями ВВНЗ потрібно звертатися до Центру дистанційного навчання. У цьому сенсі більш гнучкім $\epsilon$ варіант використання власного сервера ВВНЗ.

Найкращий варіант розробити спеціальне програмне забезпечення за результатами тестувань розробленого макету із залученням фахівців відповідних ВВНЗ. Цей шлях дозволить уникнути багатьох помилок при складанні технічного завдання на ДКР. 
Висновки. Розвиток сучасних інформаційних технологій дозволяє перейти до оцінки професійних компетентностей офіцерів - випускників вищих військових навчальних закладів тактичного рівня за спеціалізаціями шляхом розробки нових форм відгуків та анкет самооцінки 3 подальшою автоматизацією їх збору та обробки. Такий зворотній зв'язок дозволяє оперативно вносити зміни в освітні програми і якість їх викладання.

Напрями подальших досліджень пов'язані 3 проведенням пілотного тестування розробленого макету автоматизованої системи на базі одного 3 ВВНЗ та розробкою ТЗ на ДКР.

\section{ЛІТЕРАТУРА}

1. Зельницький А.М. Відгук на випускника ВВНЗ, ВНП ЗВО у системі управління якістю підготовки військових фахівців/ Вісник Національного університету оборони України. - 2011. - №1. - С.14-25.

2. Зельницький А.М. Компетентнісна модель випускника ВВНЗ - складова системи підготовки військових фахівців/ Зельницький А.М., Удовенко П. І., Серветник Р.М. / Вісник Національного університету оборони України. - 2009. - №3. - С.21-26.

3. Інноваційний розвиток вищої військової освіти України : монографія ./ В.В. Сідаш, А.М. Алімпієв, Г.В. Пєвцов, С.В. Залкін, С.О. Сідченко, К.І. Хударковський - Харків: Цифрова друкарня №1, 2012. - 456 с.

4. Горбачевський С.К., Орда М.В. Напрямки використання сучасних технологій в інформаційному забезпеченні системи військової освіти / Збірник наукових праць "Військова освіта"- №1 (41), - 2020. - С. 103-109.

\section{REFERENCES}

1. Zelnytskyi A.M. Vidhuk na vypusknyka VVNZ, VNP ZVO u systemi upravlinnia yakistiu pidhotovky viiskovykh fakhivtsiv/ Visnyk Natsionalnoho universytetu oborony Ukrainy. - 2011. №1. - S.14-25.

2. Zelnytskyi A.M. Kompetentnisna model vypusknyka VVNZ - skladova systemy pidhotovky viiskovykh fakhivtsiv/ Zelnytskyi A.M., Udovenko P. I., Servetnyk R.M. / Visnyk Natsionalnoho universytetu oborony Ukrainy. - 2009. - №3. - S.21-26.

3. Innovatsiinyi rozvytok vyshchoi viiskovoi osvity Ukrainy: monohrafiia ./ V.V. Sidash, A.M. Alimpiiev, H.V. Pievtsov, S.V. Zalkin, S.O. Sidchenko, K.I. Khudarkovskyi - Kharkiv: Tsyfrova drukarnia №1, 2012. - $456 \mathrm{~s}$.

4. Horbachevskyi S.K., Orda M.V. Napriamky vykorystannia suchasnykh tekhnolohii v informatsiinomu zabezpechenni systemy viiskovoi osvity / Zbirnyk naukovykh prats "Viiskova osvita"- №1 (41), - 2020. - S. 103-109.

\section{РЕЗЮМЕ}

Сергей Горбачевський, кандидат технических наук, старший научный сотрудник Национальный университет обороны Украины имени Ивана Черняховского

\section{Информационная система оценки профессиональной компетентности офицеров - выпускников высших военных учебных заведений тактического уровня}

Предложена структура информационной системь оиенки профессиональных компетенций офищеров - выпускников высших военных учебных заведений тактического уровня и описано макет системы на базе системы дистанционного обучения. 
Ключевые слова: информационная система; профессиональные компетенции офицеров; высшие военные учебные заведение; военное образование; дистанционное обучение.

\section{SUMMARY}

Serhii Horbachevsky,

$\mathrm{PhD}$ (technical sciences), Senior Researcher

National University of Defence of Ukraine named after Ivan Chernyakhovskyi

\section{Information system for assessing the professional competence of officers - graduates of higher military educational institutions of the tactical level}

Introduction. Digital technologies are rapidly changing modernity, especially the education system. At the same time, the digitalization of education is changing the approaches to assessing the quality of education. At the stage of training cadets (students) the degree of digitalization of the educational process and the process of assessing the quality of education is already advanced, primarily due to the system of distance learning. However, the collection of reviews on graduates of higher military educational institutions (HMEIs) and their processing is still mostly manual, although there are all the prerequisites and opportunities for its automation.

Reviews on HMEIs graduates is the main form of feedback on the quality of graduate training. In general, the system of preparation of responses to graduates, their collection and analysis should be an element of the general system of quality management of education and one of the subsystems of decision support of the head of military education.

Purpose - development of requirements for the information system for assessing the professional competencies of officers by automatization the collection and processing of reviews on graduates of HMEIs.

Methods: the system of general scientific, theoretical and empirical research special methods, methodological analysis of the problem, systematization and generalization of scientific information concerning the nature and content of certain tasks, monitoring of existing systems were used to solve the set research problems, method of information data processing.

Results. The structure of the information system for assessing the professional competencies of officers - graduates of higher military educational institutions of the tactical level is proposed and the layout of the system based on the distance learning system is described.

Originality. The article describes ways to improve the assessment of professional competencies of officers - graduates of higher military educational institutions of tactical level.

Conclusion. The development of modern information technologies allows to move to the assessment of professional competencies of officers - graduates of higher military educational institutions of tactical level by specialization by developing new forms of responses and selfassessment questionnaires with further automation of their collection and processing. Such feedback allows to operatively make changes in educational programs and the quality of their teaching.

Key words: information system; professional competence of officers; higher military educational institutions; military education; reviews on graduates. 